\title{
Anteseden Kompetensi Sumber Daya Manusia Islami dalam Menghadapi Revolusi Industri 4.0 Bagi Lembaga Keuangan Berbasis Syariah
}

\author{
Anggia Sari Lubis ${ }^{1)^{*}}$, Munawaroh ${ }^{2}$ \\ $\left.{ }^{1 *}, 2\right)$ Program Studi Manajemen, Fakultas Ekonomi, Universitas Muslim Nusantara \\ Al Washliyah \\ Jalan Garu 2A No. 93 Medan \\ E-mail: anggiasarilubis@gmail.com ${ }^{1 *}$
}

\begin{abstract}
ABSTRAK
Dalam menghadapi revolusi industri 4.0, sumber daya manusia harus memiliki kompetensi yang sesuai dengan perubahan yang diakibatkan oleh era revolusi industri. Penelitian ini bertujuan untuk mengetahui dan menganalisis anteseden kompetensi sumber daya manusia Islami dalam menghadapi revolusi industri 4.0 bagi lembaga keuangan berbasis syariah. Data diolah menggunakan Structural Equation Modeling-Partial Least Square (SEM-PLS) dengan menggunakan Smart PLS. Populasi penelitian ini adalah seluruh pegawai lembaga keuangan syariah di Kota Medan yang meliputi perbankan syariah, asuransi syariah dan pegadaian syariah. Metode penarikan sampel adalah simple random sampling. Variabel motivasi kerja memiliki pengaruh yang paling signifikan terhadap kompetensi sumber daya manusia Islami dalam menghadapi revolusi industri 4.0 dengan nilai $\mathrm{T}$ Value paling besar dari variabel lain yaitu 5.923. Hal ini menunjukkan bahwa untuk membentuk kompetensi sumber daya manusia Islami di dalam diri karyawan, maka perusahaan perlu meningkatkan motivasi kerja karyawan.
\end{abstract}

Kata Kunci: Efikasi Diri; Kompetensi Sumber Daya Manusia Islami; Karakteristik Individual; Motivasi Kerja; Revolusi Industri 4.0

\begin{abstract}
In Facing the industrial revolution 4.0 human resources must have competencies that match the changes caused by the industrial revolution era. This study aims to determine and analyze the antecedents of Islamic human resource competencies to face the industrial revolution 4.0 for sharia-based financial institutions. Data were processed by Structural Equation Modeling-Partial Least Square (SEM-PLS) and using Smart PLS software. The population of this study is all employees of sharia financial institutions in Medan, including sharia banking, sharia insurance and sharia pawn. The sampling method in this research is simple random sampling. The work motivation variable has the most significant influence on the competence of Islamic human resources in facing the industrial revolution 4.0 with the $T$ value are 5.923. This implies that to form Islamic human resource competencies to the employees, companies have to increase employee motivation.
\end{abstract}

Keyword: Industrial Revolution 4.0; Individual Characteristics; Islamic Human Resource Competencies; Self-Efficacy; Work Motivation.

\section{PENDAHULUAN}

Revolusi industri 4.0 menawarkan potensi dan tantangan yang sangat beragam bagi perusahaan. Perusahaan harus dapat menyesuaikan diri dengan berbagai peluang dan tantangan yang akan dihadapi di era revolusi industri 4.0 agar dapat bertahan dan dapat terus 
mencapai tujuan-tujuan perusahaan. Perusahaan dapat bertahan dan mencapai tujuantujuannya, terutama dengan adanya dukungan utama yang datang dari sumber daya manusia. Sumber daya manusia yang dalam hal ini adalah karyawan merupakan kunci sukses yang dibutuhkan perusahaan di dalam lingkungan yang kompetitif. Para karyawan lembaga keuangan berbasis syariah, tidak hanya harus memiliki kompetensi yang sesuai dengan kebutuhan untuk mengahadapi era revolusi industri 4.0 tetapi harus tetap melekatkan karakteristik Islami di dalam dirinya.

Karyawan harus mampu beradaptasi dengan perubahan lingkungan internal dan eksternal yang muncul akibat dari revolusi industri 4.0. Hecklau et al (2016) meneliti tentang kompetensi masa depan yangg harus dimiliki karyawan dalam menghadapi revolusi industri 4.0 dan merupakan konsep baru yang berkembang sebagai bagian dari keseluruhan Revolusi Industri ke-4. Kompetensi dalam menghadapi revolusi industri 4.0 merupakan perpaduan antara hard skill dan soft skill.

Hard skill dalam hal ini tidak hanya memiliki pengetahuan dan keahlian terkait dengan pekerjaa yang dilakukan, tetapi juga memiliki pengetahuan di bidang information, communication dan technology serta penguasaan penggunaan software untuk meningkatkan efektivitas dan efisiensi dalam bekerja. Soft skill juga memiliki peranan penting untuk sukses dalam menghadapi tantangan dan peluang di era revolusi industri 4.0 seperti kemampuan komunikasi efektif, kepemimpinan, pengambilan keputusan berkualitas, kerja sama tim, manajemen waktu dan keahlian negosiasi. Kompetensi sumber daya manusia selain harus disesuaikan dengan tuntutan di era revolusi industri 4.0, juga harus tetap berpegang pada konsep Islami sebagai ciri lembaga keuangan berbasis syariah. Sehingga penelitian ini akan membahas mengenai anteseden kompetensi sumber daya manusia Islami dalam menghadapi revolusi industri 4.0 bagi lembaga keuangan berbasis syariah, yang merupakan sebuah konsep unik dimana kompetensi tidak hanya disesuaikan dengan perkembangan revolusi industri, tetapi juga mengangkat karakteristik Islami bagi karyawan lemabaga keuangan syariah.

Kompetensi meliputi pengetahuan, kemampuan, nilai, dan kemampuan untuk menggunakan pengetahuan dan merupakan dasar untuk penilaian dan peningkatan kualitas SDM yang professional (Yue Suen, En Hsiao \& Min Yang, 2011). Kompetensi sumber daya manusia harus disesuaikan dengan kebutuhan keahlian, pengetahuan dan kemampuan yang dipersyaratkan oleh kebutuhan perusahaan yang tentunya dipengaruhi oleh faktor eksternal dan faktor internal. Salah satu fenomena yang mempengaruhi berubahnya kompetensi sumber daya manusia yang dibutuhkan perusahaan bagi karyawannya adalah datang dari revolusi industry 4.0. Saat ini dunia bisnis semakin dipermudah dengan adanya teknologi robotik, 
artificial intelligence, internet of things, big data, otomatisasi di segala bidang, yang kesemuanya terangkum di dalam konsep revolusi industri 4.0 (Andresen \& Kleiner, 2005) . Karyawan harus memiliki kompetensi yang dipersyaratkan untuk dapat menghadapi tantangan revolusi industri 4.0. Bagi lembaga keuangan berbasis syariah tidak hanya dituntut untuk memiliki kompetensi yang dipersyaratkan bagi revolusi industry 4.0, tetapi juga harus tetap mempertahankan aspek keislaman (Al-Qur`an dan As-Sunnah) di dalam dirinya. Peneliti melakukan sintesis atas indikator kompetensi sumber daya manusia Islami dalam menghadapi revolusi industri 4.0 yang ditinjau dari penelitian Hecklau et al (2016) dan Bariah et. al.,(2015) dalam Kurniawati (2017) diantaranya adalah sebagai berikut: Karakter Islami yang terdiri dari; memiliki etika dan moral yang didasarkan pada Al Qur`an dan Hadist; memiliki intelektualitas yang didasarkan pada Intellectual Quotient, Emotional Quotient, dan Spiritual Quotient; serta memiliki komitmen terhadap pekerjaan dan perusahaan; pengetahuan di bidang lembaga keuangan; memiliki pengetahuan di bidang lembaga keuangan konvensional, syariah maupun fiqh muamalah; Soft skill 4.0; Berpikir analitis, komunikasi efektif, keahlian manajerial, kepemimpinan, pengambilan keputusan berkualitas; Hard skill 4.0 : Pengetahuan dan keahlian terkait dengan pekerjaan dan jabatan Pengetahuan teknologi informasi dan komunikasi dan keahlian coding.

Pelatihan merupakan bagian dari aktivitas pengembangan karyawan yang dilakukan perusahaan untuk memperkecil gap kompetensi agar dukungan pencapaian visi dan misi perusahaan dapat lebih optimal. Pelatihan dilakukan sebagai upaya untuk meningkatkan kemampuan, keahlian, dan pengetahuan karyawan yang bertujuan untuk peningkatan mutu kerja karyawan. Menurut Mathis (2012), Pelatihan adalah suatu proses dimana orang-orang mencapai kemampuan tertentu untuk membantu mencapai tujuan organisasi. Banyak penelitian terdahulu yang membahas hubungan antara pelatihan dengan peningkatan kompetensi sumber daya manusia. Efektivitas pelatihin dapat dilihat dari pemahaman karyawan atas materi yang disampaikan saat mengikuti aktivitas pelatihan, dan melakukan implementasi materi pelatihan pada pekerjaan sehari-hari. Peningkatan sasaran kerja dan peningkatan kompetensi salah satunya dapat diwujudkan dengan adanya program pelatihan bagi karyawan (Aditya, 2015). Penelitian mengenai kompetensi kewirausahaaan yang dilakukan oleh Cherarghi \& Schottt (2014) menjelaskan bahwa pendidikan dan pelatihan kewirausahaan sangat bermanfaat untuk menumbhkan kompetensi kewirausahaan seseorang. Indikator variabel pelatihan dalam penelitian ini meliputi: Metode Pelatihan; Materi Pelatihan dan Pelatih. Penelitian yang dilakukan oleh Mokhtar \& Susilo (2017) menemukan bahwa Metode Pelatihan, Materi Pelatihan, dan Instruktur Pelatihan) mempunyai pengaruh yang 
signifikan terhadap Kompetensi Tenaga Kerja. H1: Pelatihan berpengaruh positif dan signifikan terhadap kompetensi sumber daya manusia islami dalam menghadapi revolusi industri 4.0 bagi lembaga keuangan berbasis syariah.

Karakteristik individu merupakan perbedaan individu dengan individu lainnya. Perbedaan ini akan terbawa dalam dunia kerja, yang akan menyebabkan kepuasan satu orang dengan yang lain berbeda pula meskipun bekerja di tempat yang sama. Karakteristik individu memiliki komponen seperti umur, tingkat pendidikan, Pengalaman kerja dan Keahlian. Tinjauan literature menunjukkan bahwa terdapat research gap dimana penelitian yang dilakukan oleh Suhartono (2017) menemukan bahwa karakteristik individu tidak memiliki pengaruh terhadap kompetensi pegawai. Salah satu factor yang mempengaruhi kompetensi pegawai dalam menjalankan pekerjaanya adalah karakteristik individu yang dimiliki oleh karyawan yang mendukung peningkatan kualitas kerja karyawan (Garavan\&Mc.Guire, 2001). Karakteristik individu seperti kesediaan untuk belajar, dan keahlian interpersonal sangat diperlukan untuk kompetensi auditor syariah pada perbankan syariah. Indikator Karakteristik individual adalah: Kemampuan untuk menghadapi perubahan; Kecerdasan ; Kepribadian Islami; Persepsi atas perubahan; Sikap dalam menghadapi perubahan. H2: Karakteristik individu berpengaruh positif dan signifikan terhadap kompetensi sumber daya manusia islami dalam menghadapi revolusi industri 4.0 bagi lembaga keuangan berbasis syariah.

Efikasi diri merupakan konsep yang dikemukakan oleh Bandura seorangg ahli ilmu psikologi dengan social cognitive theory merupakan teori yang memayungi konsep efikasi diri ini. Efikasi diri bagi karyawan merupakan keyakinan yang dimiliki oleh seseorang atas kemampuannya untuk dapat menjalankan tugas yang berkaitan dengan pekerjaannya dengan hasil yang baik dan maksimal. Friedman dan Schustack dalam Woropinasti (2010) mendefinisikan bahwa efikasi diri sebagai keyakinan mengenai kompetensi dan kemampuan diri dan berkaitan dengan besarnya keyakinan seseorang untuk menyelesaikan suatu tugas secara berhasil. Penelitian yang dilakukan oelh Rizky \& Fasikhah (2019) menemukan bahwa efikasi diri dapat menjelaskan pengaruhnya terhadap kompetensi emosioneal seorang guru sebesar 45,7\%. Karyawan yang memiliki kompetensi tinggi dan adaptatif terhadap perubahan baik yang berasal dari internal maupun eksternal perusahaan merupakan salah satu keunggulan komptetitif perusahaan. Karyawan yang memiliki efikasi diri yang baik akan membentuk kompetensi unggul di dalam dirinya (Suwito, 2017). Penelitian yang dilakukan oleh Haber, Pollack \& Humphrey (2014) menemukan bahwa Hasil kerja karyawan yang berkualitas didukung oleh kompetensi unggul karyawan yang salah satunya terkait dengan aspek emosi pribadi yang memiliki keyakinan atas kemampuan karyawan tersebut dalam 
menghasilkan hasil kerja yang berkualitas. Indikator Efikasi Diri diantaranya: Past Performace; Vicarious Experience; Verbal Persuasion dan Emotional Cues. H3: Efikasi diri berpengaruh positif dan signifikan terhadap kompetensi sumber daya manusia islami dalam menghadapi revolusi industri 4.0 bagi lembaga keuangan berbasis syariah.

Karyawan yang memiliki motivasi kerja positif menjadi factor penentu pencapaian prestasi dan kinerja karyawan. Banyak penelitian yang meneliti mengenai pengaruh motivasi kerja terhadap kinerja karyawan. Peneliti tertarik untuk menghubungkan terlebih dahulu motivasi kerja terhadap kompetensi karyawan sebelum pada akhirnya kinerja karyawan yang tinggi dapat dicapai. Motivasi kerja merupakan motif yang berasal dari dalam diri karyawan yang merupakan factor penentu untuk bertindak yang bertujuan untuk menyesuaikan kompetensi dengan kebutuhan perusahaan. Satria \& Kuswara (2013) menjelaskan bahwa motivasi kerja mampu mempengaruhi kompetensi kerja karyawan dengan pengaruh langsung sebesar $22,85 \%$. Karyawan yang memiliki motivasi kerja yang positif tentu akan selalu memiliki keinginan untuk meningkatkan kualitas kompetensi yang ada pada dirinya untuk pencapaian kinerja yang baik, yang tentunya dapat mendukung pencapaian visi, misi dan tujuan perusahaan. Tetapi Maulana (2016) justru dalam penelitiannya justru menemukan bahwa motivasi kerja tidak memiliki pengaruh yang signifikan terhadap kompetensi karyawan. Selanjutnya Shamshudin \& Chuttipattana (2012) menyatakan bahwa kepribadian dan motivasi merupakan factor penentu kompetensi manajerial seorang manajer. H4: Motivasi kerja berpengaruh positif dan signifikan terhadap kompetensi sumber daya manusia islami dalam menghadapi revolusi industri 4.0 bagi lembaga keuangan berbasis syariah.

Berangkat dari latar belakang penelitian, tujuan, manfaat penelitian, kajian teoritik dan empirik yang telah diuraikan di bagian muka, dapat dijadikan sebagai landasan untuk membuat model konseptual pada penelitian ini. Kompetensi Sumber Daya Manusia Islami merupakan konsep kompetensi dan keahlian yang harus dimiliki oleh sumber daya manusia dalam menghadapi revolusi industri 4.0, yang mengancam keberadaan man (sumber daya manusia) karena peran dan fungsi nya yang akan tergantikan oleh mesin. Lembaga keuangan syariah harus menyesuaikan diri dengan tantangan dan peluang dalam menghadapi revolusi industri 4.0, selanjutnya para karyawan juga harus memiliki kompetensi yang dibutuhkan dalam menghadapi era industri 4.0.

\section{METODE PENELITIAN}

Penelitian ini menggunakan pendekatan penelitian kuantitatif dengan deskriptif statistik. Jenis penelitian yang digunakan dengan metode survey, yaitu penelitian yang 
mengambil sampel dari suatu populasi dan menggunakan kuesioner sebagai alat pengumpulan data. (Sugiyono, 2012). Sifat penelitian yaitu explanatory research.

Dalam penelitian ini, yang menjadi populasi adalah seluruh pegawai Bank dan Non Bank di Kota Medan, yang terdiri dari perbankan syariah, asuransi syariah dan pegadaian syariah. Sampel didefinisikan sebagai bagian dari populasi secara keseluruhan yang dipilih, yang bertujuan umtuk dapat merepresentasikan populasi secara keseluruhan. Dalam penelitian ini penentuan besarnya sampel untuk SEM adalah sebagai berikut:

1. Bila pendugaan parameter menggunakan metode maximum likelihood, maka besar sampel sebaiknya adalah antara 100-200 dengan minimum sampel sebesar 50.

2. Sampel dihitung berdasarkan 5 hingga 10 kali jumlah parameter yang ada di dalam model

3. Sampel dihitung berdasarkan 5 hingga 10 kali jumlah indikator dari keseluruhan variabel dependen dan independen.

Penelitian ini merujuk pada aturan ketiga, maka peneliti menetapkan 5 kali jumlah indikator penelitian. Hal ini dilakukan agar jumlah sampel lebih representatif, sehingga ukuran sampel diambil $\mathrm{n}=5 \mathrm{x}$ jumlah indikator, yaitu: $\mathrm{n}=5 \times 18=90$ responden. Teknik sampling yang digunakan adalah simple random sampling. Dalam penelitian ini metode analisis data yang digunakan adalah structural equation modeling-partial least squares (SEM-PLS) dengan menggunakan software SmartPLS Selanjutnya akan disajikan konversi model jalur (Gambar 1) ke dalam bentuk persamaan struktural partial least square (PLS) untuk menyatakan hubungan kausalitas antar berbagai konstruk.

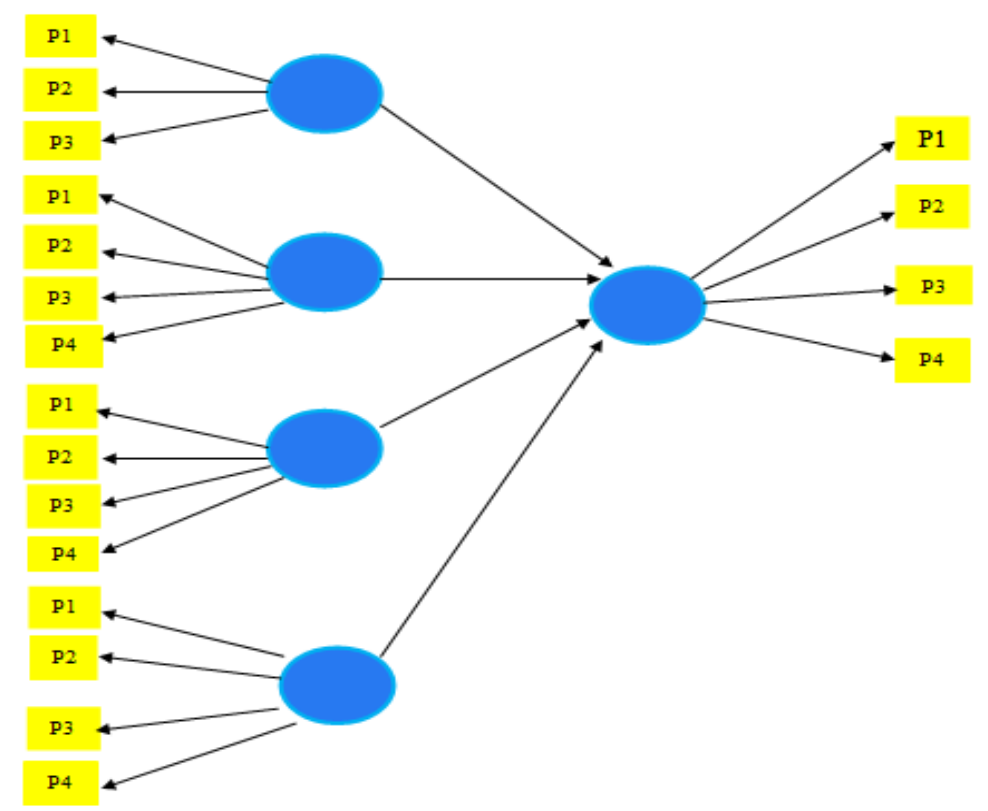

Gambar 1. Hierarchical Component Model SEM-PLS 
Berikut adalah konversi model jalur (Gambar 1) ke bentuk persamaan truktural PLS untuk menyatakan hubungan kausalitas antarberbagai konstruk asalah sebagai berikut:

\section{A. Outer Model}

Untuk variabel laten eksogen 1 (reflektif):

$$
\begin{aligned}
& \mathrm{x} 1=\lambda \mathrm{x} 1 \xi 1+\delta 1 \\
& \mathrm{x} 2=\lambda \times 2 \xi 2+\delta 2 \\
& \mathrm{x} 3=\lambda \times 3 \xi 3+\delta 3 \\
& \mathrm{x} 4=\lambda \times 4 \xi 4+\delta 4
\end{aligned}
$$

Untuk variabel laten endogen 1 (reflektif)

$\mathrm{y} 1=\lambda \mathrm{y} 1 \eta 1+\varepsilon 1$.

B. Inner Model:

$\eta 1=\gamma 1 \xi 1+\gamma 2 \xi 2+\gamma 3 \xi 3+\gamma 4 \xi 4+\zeta 1 \ldots(6)$

Keterangan:

$\xi=$ Ksi, variabel laten eksogen

$\eta=$ Eta, variabel laten endogen

$\lambda \mathrm{x}=$ Lamnda (kecil), loading factor variabel laten eksogen

$\lambda y=$ Lamnda (kecil), loading factor variabel laten endogen

$\beta=$ Beta (kecil), koefisien pengaruh endogen terhadap endogen

\begin{tabular}{|c|c|c|}
\hline A & Variabel Laten Eksogen & Jumlah variabel proksi/indikator \\
\hline 1 & Pelatihan & 3 indikator $\left(\mathrm{x}_{1.1}-\mathrm{x}_{1.3}\right)$ \\
\hline 2 & Karakteristik Individu & 4 indikator $\left(\mathrm{x}_{2.1}-\mathrm{x}_{2.4}\right)$ \\
\hline 3 & Efikasi Diri & 4 indikator $\left(\mathrm{x}_{3.1}-\mathrm{x}_{3.4}\right)$ \\
\hline 4 & Motivasi Kerja & 4 indikator $\left(\mathrm{x}_{4.1}-\mathrm{x}_{4.4}\right)$ \\
\hline B & Variabel Laten Endogen & Jumlah variabel proksi/indikator \\
\hline 5 & Kompetensi SDM Islami & 5 indikator $\left(\mathrm{y}_{1.1}-\mathrm{y}_{1.4}\right)$ \\
\hline
\end{tabular}

$\gamma=$ Gamma (kecil), koefisien pengaruh eksogen terhadap endogen

$\zeta=$ Zeta (kecil), galat model.

\section{Tabel 1. Variabel-Variabel dalam Model}

\section{HASIL DAN PEMBAHASAN}

Validitas konvergen merupakan bagian dari measurement model (model pengukuran) yang dalam SEM-PLS biasanya disebut sebagai outer model sedangkan dalam covariance- 
based SEM disebut confirmatory factor analysis (CFA) (Mahfud dan Ratmono, 2013). Terdapat dua kriteria untuk menilai apakah outer model (model pengukuran) memenuhi syarat validitas konvergen untuk konstruk reflektif, yaitu (1) loading harus di atas 0,7 dan (2) nilai p signifikan $(<0,05)$ (Hair dkk. dalam Mahfud dan Ratmono, 2013).

Indikator-indikator yang telah merefleksikan konstruknya secara konsisten dan stabil dengan syarat loading factor > 0,7 adalah X1.1, X1.2,X1.3, X2.1, X2.2, X2.3,X2.4, X3.1,X3.2, X3.3, X3.4, X4.1, X4.2, X4.3, X4.4, Y1.1, Y1.2, Y1.3,Y1.4. Cronbach's Alpha untuk X1, X2, X3, X4, Y1 bernilai di atas 0,7. Artinya masing-masing variabel laten telah memenuhi syarat reliabilitas berdasarkan cronbach alpha. Nilai Average Variance Extracted (AVE) untuk $\mathrm{X} 1, \mathrm{X} 2, \mathrm{X} 3, \mathrm{X} 4, \mathrm{Y}$ bernilai di atas 0,5 , artinya telah memenuhi syarat validitas berdasarkan AVE.

Evaluasi Penilaian Inner Model. Hubungan antar konstruk laten, dalam penelitian ini hanya melihat hubungan langsung antara pelatihan,karakteristik individu, efikasi diri serta motivasi kerja dengan kompetensi sumber daya manusia Islami dengan melihat inner model melalui uji signifikansi pengaruh langsung (direct effect). Model struktural atau model inner dievaluasi dengan melihat nilai koefisien jalur, P values, nilai goodness of fit, effect size, dan nilai koefisien determinasi.

Konstruk kompetensi sumber daya manusia Islami (Y) memiliki nilai $\mathrm{R}^{2} 0,710$, berarti pelatihan, karakteristik individu, efikasi diri dan motivasi kerja mampu menjelaskan pengaruhnya terhadap kompetensi sumber daya manusia Islami sebesar 71,0\% sedangkan $29,0 \%$ dijelaskan oleh variabel lain yang tidak diteliti pada penelitian ini. Nilai $\mathrm{R}^{2}$ pada konstruk kompetensi sumber daya manusia tergolong tinggi atau moderat. Nilai Goodness of fit (GoF) model adalah 0,801, dapat dikatakan tergolong kepada kategori yang besar. Sehingga model konstruk jaringan kerjasama pelatihan, karakteristik individu, efikasi diri dan motivasi kerja, dengan kompetensi sumber daya manusia Islami memiliki performa yang baik dan memvalidasi model secara keseluruhan dengan baik.

Effect size $\mathrm{f}^{2}$ dimana motivasi kerja (X4) dapat menjelaskan model dengan baik yang memiliki nilai 0,367 (moderat menuju substansial), sehingga jika motivasi kerja dikeluarkan dari model maka nilai keragaman model akan berkurang dari $\mathrm{R}^{2}=0,710$ menjadi $\mathrm{R}^{2}=$ 0,606. Nilai $\mathrm{f}^{2}$ pada pelatihan, karakteristik individu dan efikasi diri tergolong lemah.

Pada kriteria prediction relevance, karakteristik individu, efikasi diri, motivasi kerja, dan kompetensi sumber daya manusia Islami memiliki nilai $\mathrm{Q}^{2}>0$, artinya variabel laten sudah mampu memprediksi model dengan baik. Nilai $\mathrm{Q}^{2}$ pada $\mathrm{X} 1=0$, menunjukkan rendahnya kemampuan dari variabel pelatihan menjelaskan model dengan baik. 
Tabel 2. Nilai Kriteria Hasil Penelitian Model Pengukuran (Outer Model)

\begin{tabular}{|c|c|c|c|}
\hline No. & $\begin{array}{l}\text { Kriteri } \\
\mathbf{a} \\
\end{array}$ & $\begin{array}{l}\text { Rule of } \\
\text { thumbs }\end{array}$ & Nilai hasil penelitian \\
\hline 1 & Cronbach's Alpha & $>0,7$ & $\begin{array}{l}\mathrm{X}_{1}=1.000(\text { reliabel}) ; X_{2}=0,942 \\
\left(\text { reliabel) } X_{3}=0.872 \text { (reliabel); } X_{4}=\right. \\
0,997 \text { (reliabel) } \\
Y_{1}=0.743 \text { (reliabel) }\end{array}$ \\
\hline 2 & Realibilitas komposit $\left(\mathrm{p}_{\mathrm{c}}\right)$ & $>0,7$ & $\begin{array}{l}\mathrm{X}_{1}=1.000 \text { (reliabel); } \mathrm{X}_{2}=0,967 \\
\text { (reliabel) } \mathrm{X}_{3}=0.917 \text { (reliabel); } \mathrm{X}_{4}= \\
0,999 \text { (reliabel) } \mathrm{Y}_{1}=0.891 \text { (reliabel) }\end{array}$ \\
\hline 3 & AVE & $>0,5$ & $\begin{array}{l}X_{1}=1.000 \text { (valid); } X_{2}=0,892 \\
\text { (valid) } X_{3}=0.776 \text { (valid); } X_{4}= \\
0,948 \text { (valid) } \\
Y_{1}=0.798 \text { (valid) }\end{array}$ \\
\hline
\end{tabular}

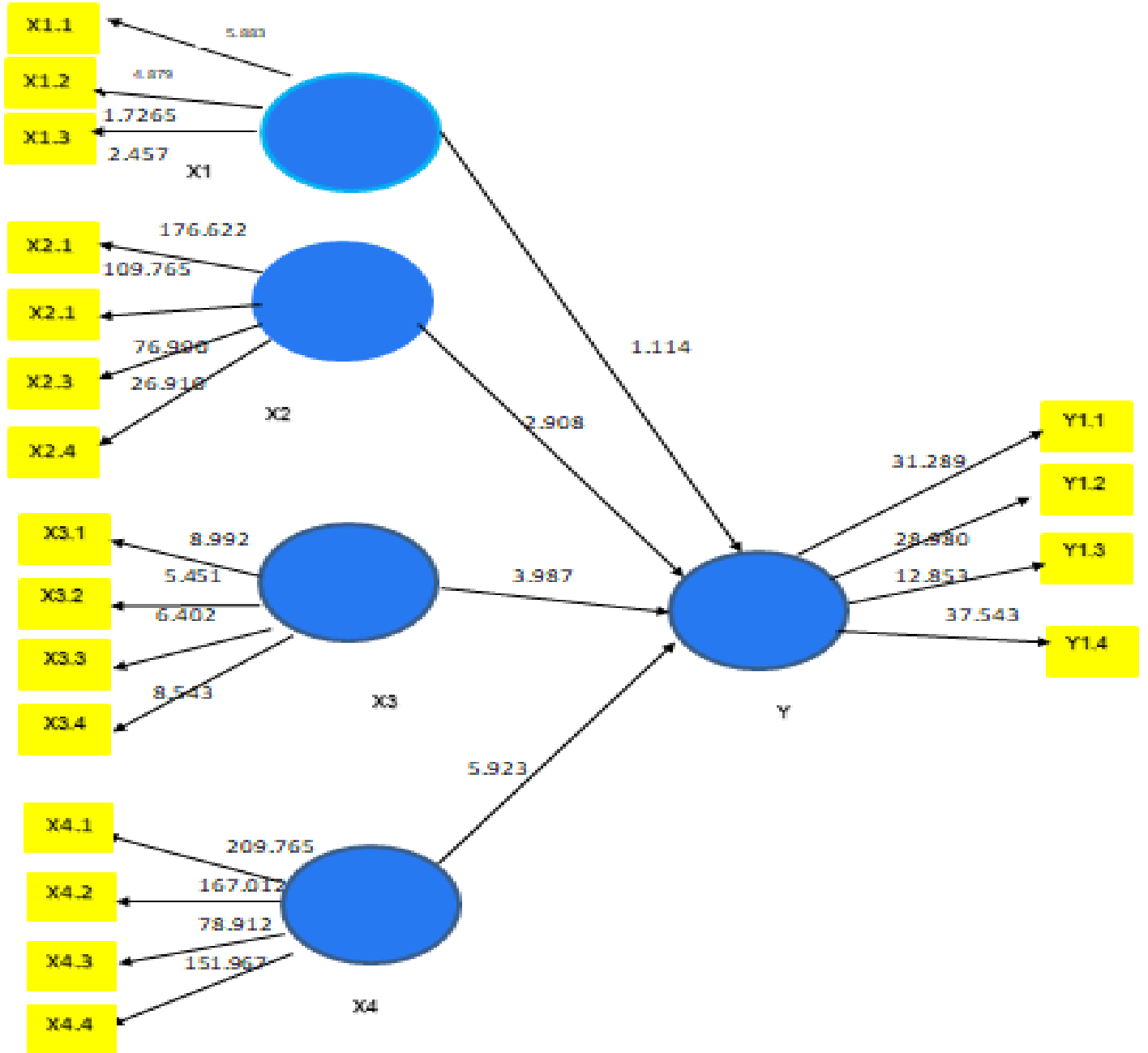

Gambar 2. Diagram Jalur Berdasarkan Nilai Loading Factor 
Tabel 3. Nilai Koefisien Jalur

\begin{tabular}{lcccc}
\hline & $\begin{array}{l}\text { Original } \\
\text { Sample }\end{array}$ & T-Value & P Value & Kesimpulan \\
\hline $\begin{array}{l}\text { Pelatihan (X) 1 } \\
\text { Kompetensi SDM Islami (Y }\end{array}$ & 0.190 & 1.114 & 0.135 & Tidak signifikan \\
$\begin{array}{l}\text { Karakteristik Individu (X ) 2 } \\
\text { Kompetensi SDM Islami (Y) }\end{array}$ & 0.576 & 2.908 & 0.012 & Signifikan \\
$\begin{array}{l}\text { Efikasi Diri (X) 3 } \\
\text { Kompetensi SDM Islami (Y) }\end{array}$ & 0.224 & 3.987 & 0.019 & Signifikan \\
$\begin{array}{l}\text { Motivasi Kerja(X) 4 } \\
\text { Kompetensi SDM Islmai (Y }\end{array}$ & 0.891 & 5.923 & 0.000 & Signifikan \\
\hline
\end{tabular}

*Nyata pada taraf $5 \%$

Berdasarkan hasil pada Tabel 3 diperoleh hasil:

Pelatihan (X1) berpengaruh positif terhadap Kompetensi sumber daya manusia Islami (Y) dengan nilai koefisien jalur 0,190 dan tidak signifikan dengan nilai P-Values 0,135 > 0,05. Karakteristik individu (X2) berpengaruh positif terhadap kompetensi sumber daya manusia Islami (Y) dengan nilai koefisien jalur 0,576 dan signifikan dengan nilai P-Values 0,012 < 0,05. Efikasi diri (X3) berpengaruh positif terhadap kompetensi sumber daya manusia Islami (Y) dengan nilai koefisien jalur 0,224 dan signifikan dengan nilai P-Values 0,019<0,05. Motivasi kerja (Y) berpengaruh positif terhadap kompetensi sumber daya manusia Islami (Y) dengan nilai koefisien jalur 0,891 dan signifikan dengan nilai P-Values $0,000<0,05$.

Kompetensi sumber daya Islami dalam menghadapi revolusi industry 4.0 yang paling signifikan dipengaruhi motivasi kerja. Seluruh variabel dalam penelitian ini memiliki pengaruh postif terhadap kompetensi sumber daya manusia Islami dalam menghadapi revolusi industry 4.0, tetapi variabel pelatihan tidak signifikan dalam mempengaruhi kompetensi sumber daya manusia Islami. Hasil penelitian ini dapat menjadi celah penelitian (research gap) bagi peneliti-peneliti selanjutnya. Karena banyak penelitian terdahulu menghasilkan pengaruh yang positif dan signifikan dari pelatihan terhadap kompetensi (Aditya, 2015; Mokhtar\& Susilo, 2017; Cherarghi \& Schottt,2014). Variabel dengan nilai koefisien jalur paling tinggi dan paling signifikan dalam mempengaruhi kompetensi sumber daya manusia Islami adalah motivasi kerja. Menurut Satria dan Kuswara (2013) menyatakan bahwa motivasi kerja dan pelatihan memiliki pengaruh yang signifikan terhadap peningkatan kompetensi kerja seorang karyawan. Kompetensi karyawan menjadi hal penting yang harus diperhatikan perusahaan karena kompetensi sudah terbukti mampu meningkatkan kinerja karyawan yang secara langsung dapat mempengaruhi peningkatan kinerja perusahaan. Motivasi dapat menjadi Selanjutnya hasil penelitian ini juga sejalan dengan penelitian 
Cherrian dan Jacob (2013) yang menyatakan bahwa motivasi dan efikasi diri memiliki pengaruh terhadap kompetensi karyawan yang pada akhirnya dapat secara linier untuk meningkatkan kinerja karyawan.

Karakteristik individu mampu mempengaruhi kompetensi sumber daya manusia Islami dalam menghadapi era revolusi industri 4.0. Karakteristik individu merupakan perbedaan mendasar yang dimiliki seorang individu yang berbeda dengan individu lainnya. Perbedaan ini akan dibawa pada dunia kerja yang antinya akan mempengaruhi kualitas hasil kerja seseorang. Karyawan dengan karakteristik individu yang selalu memiliki kemamuan untuk meningkatkan kualitas dirinya merupakan karakteristik yang diperlukan perusahaan terhadap karyawan-karyawannya. Karena pada dasarnya perusahaan selalu dihadapkan oleh perubahan dan tantangan, sehingga karyawan diharapkan dapat memberikan kontribusi untuk membantu perusahaan untuk dapat memperoleh sustainability dan memenangkan persaingan. Sanagt logis jika peneliti menghubungkan karakteristik individu dengan kompetensi karena dengan adanya karakteristik individu yang mendukung pemcapaian kompetensi yang unggul, maka perusahaan akan memiliki karyawan yang berkualitas. Karakteristik individu berpengaruh positif dan signifikan sesuai dengan hasil penelitian Garavan \& Mc Guire (2001).

Variabel efikasi diri juga memberikan pengaruh yang positif dan signifikan terhadap kompetensi sumber daya manusia Islami. Hal ini dikarenakan, dengan adanya keyakinan dalam diri atas kemampuannya untuk menyelesaikan tugas secara berkualitas, akan terus mendorong seorang karyawan untuk meningkatkan kualitas kompetensinya. Karyawan dengan efikasi diri yang tinggi akan terus berusaha beradaptasi dengan peluang dan tantangan dari era industri 4.0. Untuk beradaptasi tentunya seorang karyawan akan menyesuaikan kompetensi yang dimilikinya dengan kompetensi yang dibutuhkan untuk dapat bertahan dan sukses dalam menghadapi dunia kerja di era revolusi industri 4.0. Efikasi diri dapat mempengaruhi kompetensi sejalan dengan hasil penelitian Haber, Pollack \& Humphrey (2014) yang menemukan bahwa efikasi diri merupakan factor internal seseorang yang mampu mendukung peningkatan kompetensi yang dimilikinya.

\section{KESIMPULAN DAN SARAN}

Menggunakan VBSEM atau PLS dalam menguji anteseden kompetensi sumber daya manusia Islami yang terdiri dari pelatihan, karakteristik individu, efikasi diri dan motivasi kerja relevan dapat digunakan sebagai salah satu teknik untuk mengevaluasi kompetensi sumber daya manusia Islami. Motivasi kerja menjadi variabel yang memiliki pengaruh yang 
paling tinggi dan signifikan terhadap kompetensi sumber daya manusia Islami. Variabel yang menjadi anteseden kompetensi sumber daya manusia Islami yaitu karakteristik individu, efikasi diri juga memiliki pengaruh yang positif dan signifikan terhadap kompetensi sumber daya manusia Islami bagi karyawan lembaga keuangan berbasis syariah di Kota Medan. Tetapi pelatihan tidak signifikan dalam mempengaruhi Kompetensi sumber daya manusia Islamim hal ini dapat dijadikan researvh gap bagi peneliti selanjutnya. Karyawan harus membekali dan melengkapi diri dengan kompetensi yang dibutuhkan perusahaan untuk dapat bertahan dari tantangan yang muncul pada era revolusi industry saat ini. Selain kompetensi yang disesuaikan dengan perkembangan revolusi induatri 4.0, karyawan lembaga keuangan berbasis syariah juga tetap harus memiliki kompetensi yang tetap Islami yaitu sesuai dengan Al-Qur’an dan Hadist.

Penelitian ini hanya meneliti empat variabel anteseden kompetensi sumber daya manusia Islami dan memiliki keterbatasan atas tinjauan literature kompetensi yang lebih mendalam jika dikatikan dengan konsep Islami. Konsep Islami yang digunakan peneliti adalah pengetahuan mengenai perbankan syariah dan fiqh muammalah. Peneliti selanjutnya dapat menggali lebih dalam mengenai konsep Islami dalam kompetensi sumber daya manusia, dan menghubungkan lebih banyak variabel anteseden dari kompetensi sumber daya manusia Islami.

\section{REFERENSI}

Aditya, Rifki. (2015). Pengaruh Pelatihan terhadap Kompetensi dan Kinerja Karyawan (Studi Pada Karyawan PT. PLN (Persero) Distribusi Jawa Timur area Malang). Jurnal Administrasi Bisnis. 27 (2).

Alainati, AlShawi, AL-Karaghouili. (2010). The Effect of Education and Training on Competency. European and Mediterranean Conference on Information Systems

Ali, Shafii \&Shahimi. (2020). Competency Model for Shari'ah auditors in Islamic Banks. Journal of Islamic Accounting and Business Research. 11 (2), 377-399

Andresen\&Kleiner. (2005). Effective Human Resource Management in The Steel Industry. Management Research News, 28 (11/12), 32-43.

Armstrong, M.; Taylor, S. (2014). Armstrong's Handbook of Human Resource Management Practice. London, England: Kogan Page.

Cherargie \& Schott. (2015) Education and Training Benefiting a Career as Entrepreneur Gender Gaps and Gendered Competencies And Benefits. International Journal of Gender and Entrepreneurship. 7 (3), 321-343

Cherrian and Jacob. (2013) Impact of Self Efficacy on Motivation and Performance of Employees. International Journal of Business and Management. 8 (14)

Garavan\&Mc.Guire. (2001) Competencies and Workplace Learning: Some Reflections on The Rhetoric And The Reality. Journal of Workplace Learning. 13 (4), 144-163

Hecklau et al. (2016). Holistic Approach for Human Resource Management In Industry 4.0. Procedia CIRP $541-6$ 
Kurniawati, Rini. Model Pengembangan Kompetensi SDM Berbasis Islamic Values pada Lembaga Keuangan Mikro Syariah. Jurisprudence, 7 (2)

Mathis, Robert L. dan John H. Jackson. (2012). Manajemen Sumber Daya Manusia, Edisi Pertama. Jakarta: Salemba Empat

Maulana, Rendy Baretta. (2016). Pengaruh Motivasi Kerja, Pendidikan dan Pelatihan (Diklat), dan Disiplin Kerja terhadap Kompetensi Pegawai dan Kinerja Pegawai. Jurnal Riset Bisnis dan Manajemen. 4 (3), 247-256

Mokhtar \& Susilo. (2017). Pengaruh Pelatihan terhadap Kompetensi (Penelitian tentang Pelatihan pada Calon Tenaga Kerja Indonesia di PT Tritama Bina Karya Malang). Jurnal Administrasi Bisnis (JAB). 50 (6)

Rizky\&Fasikhah. (2019). Pengaruh Self Efficacy terhadap Kompetensi Emosi Guru Sekolah Luar Biasa di Kota Malang. Jurnal RAP UNP. 10 (1), 1-13

Saraswati, Hamid dan Topowijono. (2015). Pengaruh Pelatihan terhadap Kompetensi Karyawan dan Kualitas Pelayanan (Studi pada Eco Green Park, Batu). Jurnal Administrasi Bisnis (JAB). 23 (2)

Satria dan Kuswara. (2013). Pengaruh Motivasi dan Pelatihan terhadap Kompetensi Kerja Serta Implikasinya pada Produktivitas Pegawai Dinas Perhubungan Kota Bandung. Jurnal Ekonomi, Bisnis \& Entrepreneurship. 7 (2), 74-83

Schuler SR. (2009) Linking Competitive Strategies with Human Resources Management Practices. The Academy of Management Excecutive; 1(3): 207-219.

Schuler SR, Jackson FS. (2009). Strategic Human Resources Management: Linking the People with the Strategic Needs of The Bussinnes. Organizational Dynamic; 12(1):18.

Shamshudin \& Chuttipattana. (2012). Determinants of Managerial Competencies for Primary Care Managers in Southern Thailand. Journal of Health Organization and Management 26 (2), 258-280

Suhartono. (2017). Pengaruh Pelatihan dan Karakteristik Individu terhadap Kinerja Dimediasi oleh Kompetensi Pegawai Badan Penanggulangan Bencana Daerah (BPBD) Kota Batu. JIMMU. 2 (2)

Ulrich D. (2018). Human Resources Champion: The Next Agenda for Adding Value and Delivering Result, Boston: Harvard Business Scholl Press.

Wiley CB. A. (2012). Comprehensive Views of Roles For Iluman Resources Managers in Industry Today. Industrial Management; 27-29.

Wickramasinghe \& De Zoyza. (2007). Gender, Age And Marital Status as Predictors of Managerial Competency Needs Empirical Evidence From a Sri Lanka Telecommunication Service Provider. Gender In Management: An International Journal, 23 (5), 337-354

Wittenstein, Robin D. (2008). Factors Influencing Individual Readiness for Change In a Health Care Environment. A Dissertation Submitted to The Faculty of The Graduate School of Education and Human Development of The George Washington University in partial fulfillment of the requirements for the degree of Doctor of Education

Yeardley, Timothy. (2017). Training of New Managers: Why are We Kidding Ourselves?. Industrial and Commercial Training. 49 (5) 
